\title{
Evaluasi Trichoderma dalam Mengendalikan Penyakit Rebah Kecambah Tanaman Cabai
}

\author{
Evaluation of Trichoderma Isolated from Lowland Swampy Soil \\ Against Damping-off in Pepper
}

\author{
Ahmad Muslim*, Komar Palimanan, Harman Hamidson, Abdullah Salim, Nirwati Anwar \\ Universitas Sriwijaya, Ogan Ilir 30662
}

\begin{abstract}
ABSTRAK
Dalam budi daya tanaman cabai, penyakit rebah kecambah merupakan faktor pembatas yang sangat penting dalam produksi. Penelitian ini bertujuan menentukan kemampuan 14 isolat Trichoderma yang diisolasi dari lahan rawa lebak di Sumatera Selatan dalam mengendalikan serangan penyakit rebah kecambah. Hasil penelitian menunjukkan bahwa isolat Trichoderma dapat menghambat perkembangan penyakit rebah kecambah yang disebabkan oleh Rhizoctonia solani. Trichoderma dapat menghambat pre-emergence damping-off, post-emergence damping-off, dan keparahan penyakit berturut-turut sebesar $51.8-100 \%, 80-100 \%$, dan 51.90-96.96\%. Perlakuan Trichoderma juga mampu meningkatkan tinggi dan bobot basah tanaman cabai, berturut-turut $45.45-64.37 \%$ dan $37.78-81.19 \%$.

Kata kunci: agens pengendali hayati, Rhizoctonia solani, lahan rawa lebak, pemacu pertumbuhan tanaman

ABSTRACT

Damping-off disease is commonly occurred in chili pepper field and always caused significant effect on chili production. This experiment was conducted to determine the ability of 14 isolates of Trichoderma isolated from lowland swampy area in South Sumatera against damping-off disease. The result showed that treatment of Trichoderma significantly inhibited damping-off disease caused by Rhizoctonia solani. Treatment of Trichoderma effectively reduced the percentage of pre-emergence dampingoff, post-emergence damping-off, and disease severity by $51.8-100 \%, 80-100 \%$, and $51.90-96.96 \%$, respectively. The treatment was also capable to increase percentage of height and fresh weight of chili pepper seedling, i.e. $45.45-64.37 \%$ and $37.78-81.19 \%$, respectively.
\end{abstract}

Key words: biological control agent, lowland swampy area, plant growth promotin, Rhizoctonia solani

\section{PENDAHULUAN}

Lahan rawa lebak di Sumatera Selatan pada musim hujan, dominan untuk budi daya padi, sementara pada saat musim kemarau untuk tanaman sayuran di antaranya cabai. Rhizoctonia merupakan salah satu patogen yang biasanya menimbulkan penyakit rebah kecambah di persemaian cabai. Penyakit ini sangat merugikan, terutama pada bibit yang berumur 1-21 hari setelah semai.

Pengendalian hayati merupakan alternatif pengendalian yang potensial untuk dikembangkan karena aman bagi lingkungan

*Alamat penulis korespondensi: Jurusan Hama dan Penyakit Tumbuhan, Fakultas Pertanian, Universitas Sriwijaya Jalan Raya Palembang-Prabumulih, KM 32, Indralaya, Ogan Ilir 30662 Tel: 0711-580663, Faks: 0711-580059, Surel: limpal2003@yahoo.com 
Trichoderma merupakan agens hayati yang sudah dibuktikan mampu melindungi tanaman dari serangan berbagai penyakit-penyakit busuk pascapanen pada buah pisang (Adebesin et al. 2009), layu fusarium pada tanaman tomat yang disebabkan oleh Fusarium oxysporum f. sp. lycopersici (Segarra et al. 2010), layu fusarium pada tanaman hutan Dalbergia sissoo yang disebabkan oleh Fusarium solani sp. dalbergiae (Basak dan Basak 2011), penyakit rebah kecambah pada tanaman mentimun yang disebabkan oleh Rhizoctonia (Huang et al. 2011), penyakit busuk batang tanaman kentang yang disebabkan oleh Sclerotinia sclerotiorum (Ojaghian 2011).

Mengingat betapa merusaknya penyakit rebah kecambah pada tanaman cabai maka penelitian ini bertujuan menentukan kemampuan isolat Trichoderma yang diisolasi dari lahan rawa lebak untuk mengendalikan serangan penyakit rebah kecambah yang disebabkan oleh Rhizoctonia solani.

\section{BAHAN DAN METODE}

\section{Bahan}

Trichoderma yang digunakan merupakan isolat dari tanah rizosfer lahan rawa lebak di Kabupaten Ogan Ilir, Sumatera Selatan yang sudah diuji kemampuannya sebagai cendawan pemicu pertumbuhan tanaman (PPT) (Muslim et al. 2006). R. solani diisolasi dari akar tanaman cabai yang terserang penyakit rebah kecambah yang ditanam di lahan rawa lebak. Trichoderma dan $R$. solani disiapkan sebagai inokulum menggunakan substrat campuran dedak, bungkil jagung, dan merang padi kering dengan perbandingan bobot (40:30:10).

Sebanyak 80 g substrat campuran dedak, jagung, merang padi ditambah air destilasi dengan perbandingan 1:0.8 b/v. Substrat ini disterilkan menggunakan autoklaf.

Trichoderma dan $R$. solani masingmasing diremajakan pada medium agar-agar dekstrosa kentang (ADK) selama 3 hari pada suhu kamar. Selanjutnya 5-7 koloni cendawan dengan diameter $5 \mathrm{~mm}$ diinokulasikan ke substrat untuk digunakan sebagai inokulum.
Masing-masing biakan diinkubasikan selama 10-14 hari pada suhu kamar. Biakan digoyang setiap hari supaya cendawan merata dalam seluruh substrat. Selanjutnya, cendawan dikeringanginkan selama 7 hari dan disimpan pada suhu $4{ }^{\circ} \mathrm{C}$ sebelum digunakan (Muslim et al. 2003).

\section{Uji Kemampuan Trichoderma dalam Menekan Penyakit Rebah Kecambah}

Kemampuan Trichoderma menekan penyakit rebah kecambah yang disebabkan oleh $R$. solani pada tanaman cabai dilakukan secara in vivo di rumah kaca. Aplikasi dan uji kemampuan Trichoderma dalam menekan penyakit rebah kecambah mengikuti Shivanna (1995) yang dimodifikasi pada inokulumnya. Masing-masing inokulum Trichoderma dan $R$. solani dicampur dengan tanah steril pada wadah yang berbeda. Konsentrasi inokulum Trichoderma ialah $2 \%(\mathrm{~b} / \mathrm{b})$ dan $R$. solani ialah $1 \%(\mathrm{~b} / \mathrm{b})$.

Aplikasi inokulum Trichoderma dalam menekan penyakit rebah kecambah dilakukan dengan meletakkan tanah yang telah diinfestasi dengan Trichoderma dan patogen $R$. solani secara berselang-seling dengan lebar masingmasing $5 \mathrm{~cm}$ pada waktu yang bersamaan di baki plastik ukuran $30 \mathrm{~cm}$ x $27 \mathrm{~cm}$ x $7 \mathrm{~cm}$. Benih disterilkan dengan alkohol $70 \%$ selama 3 menit lalu dicuci dengan air steril sampai aroma alkohol hilang. Selanjutnya benih disemai pada tanah yang telah diinfestasi Trichoderma dengan jarak penyemaian antarbenih pada setiap baris ialah $2.5 \mathrm{~cm}$.

Peubah yang diamati ialah persentase rebah kecambah sebelum mencapai permukaan tanah (pre-emergence damping-off), persentase rebah kecambah setelah tanaman mencapai permukaan tanah (post emergence damping off), keparahan penyakit, tinggi dan bobot basah bibit.

Persentase benih terserang sebelum muncul ke permukaan tanah dihitung berdasarkan jumlah benih yang gagal berkecambah. Perhitungan dimulai sejak hari ke-1 sampai ke-10 setelah semai menggunakan rumus:

$$
\mathrm{S}=\left[\frac{\mathrm{A}-\mathrm{B}}{\mathrm{A}} \times 100 \%\right]-[100 \%-\mathrm{D}], \text { dengan }
$$


$\mathrm{S}$, persentase pre-emergence damping-off; A, jumlah benih yang disemai; $B$, jumlah kecambah muncul ke permukaan tanah; D, persentase daya kecambah benih.

Persentase post-emergence damping-off dihitung berdasarkan banyaknya kecambah yang rebah, setelah benih muncul di atas permukaan tanah. Penghitungan dimulai sejak munculnya kecambah ke permukaan tanah sampai hari ke-21 setelah semai menggunakan rumus:

$$
\mathrm{K}=\frac{\mathrm{n}}{\mathrm{N}} \times 100 \% \text {, dengan }
$$

$\mathrm{K}$, persentase bibit terserang post-emergence damping-off; $\mathrm{n}$, jumlah bibit terserang; $\mathrm{N}$, jumlah benih yang tumbuh.

Persentase keparahan penyakit dihitung dengan rumus:

$$
I=\frac{\sum n \times v}{Z \times N} \times 100 \%, \text { dengan }
$$

$I$, keparahan penyakit; $n$, jumlah bibit yang terserang; $Z$, harga numerik dari nilai kategori tertinggi; $N$, jumlah benih yang disemai; $v$, harga numerik dari setiap nilai kategori (0-5), yaitu: 0 , tidak ada penyakit; 1 , lesion muncul pada leher akar sepanjang $1 \mathrm{~mm} ; 2$, lesion cokelat sampai cokelat gelap sepanjang 2-10 mm mengelilingi akar; 3, lesion cokelat gelap sepanjang 10-25 mm dimana miselia mengolonisasi koleoptil; 4, >25 $\mathrm{mm}$ area akar menjadi hitam dan busuk pada koleoptil; 5, bibit busuk secara menyeluruh atau bibit mati.

Penekanan terhadap pre-emergence damping-off, post-emergence damping-off, dan keparahan penyakit dihitung berdasarkan rumus:

Persentase penekanan $=\frac{\mathrm{K}-\mathrm{P}}{\mathrm{K}} \times 100 \%$, dengan

$\mathrm{K}$, nilai pada kontrol; P, nilai pada perlakuan.

Tinggi tanaman dan bobot basah diamati pada hari terakhir pengamatan, yaitu ketika bibit berumur 21 hari setelah semai. Persentase peningkatan tinggi tanaman dan bobot basah dihitung berdasarkan pada rumus:

Persentase peningkatan $=\frac{\mathrm{K}-\mathrm{P}}{\mathrm{K}} \times 100 \%$, dengan

$\mathrm{K}$, nilai pada kontrol; $\mathrm{P}$, nilai pada perlakuan.
Penelitian ini disusun dalam rancangan acak lengkap dengan 15 perlakuan, yang terdiri atas kontrol dan 14 perlakuan isolat Trichoderma (galur T1, T2, T3, T4, T5, T6, T7, T8, T9, T10, T11, T12, T13, dan T14). Masing-masing perlakuan diulang 3 kali dan masing-masing ulangan sebanyak 30 bibit.

Data yang diperoleh dianalisis menggunakan analysis of variance dan jika perlakuan berbeda nyata dengan kontrol maka antarperlakuan diuji menggunakan uji beda nyata jujur. Analisis dilakukan menggunakan SAS 9.0.

\section{HASIL}

\section{Penyakit Rebah Kecambah}

Perlakuan semua Trichoderma memberikan pengaruh nyata dalam menghambat preemergence damping-off pada bibit cabai. Hampir semua perlakuan Trichoderma efektif menghambat pre-emergence damping-off, bahkan Trichoderma galur T5, T10, T12, dan T13 dengan sempurna menghambat preemergence damping-off (Tabel 1).

Perlakuan Trichoderma pada pembibitan cabai memberikan pengaruh yang nyata terhadap post-emergence damping-off. Perlakuan Trichoderma sangat efektif menghambat perkembangan post-emergence damping-off dengan persentase penghambatan yang tinggi, bahkan Trichoderma galur T4, T7, dan T8 menghambat dengan sempurna $100 \%$ (Tabel 2).

\section{Keparahan Penyakit}

Perlakuan Trichoderma yang diaplikasikan bersamaan waktunya dengan patogen $R$. solani juga menunjukkan pengaruh yang nyata dalam menghambat keparahan penyakit. Keparahan penyakit pada perlakuan Trichoderma jauh lebih rendah dibandingkan dengan kontrol. Semua perlakuan Trichoderma, kecuali Trichoderma galur T8, sangat efektif menghambat perkembangan penyakit (Tabel 3).

\section{Tinggi dan Bobot Basah Bibit}

Perlakuan Trichoderma pada pembibitan juga memberikan pengaruh nyata terhadap 
Tabel 1 Perlakuan Trichoderma dalam penghambatan terhadap penyakit rebah kecambah yang disebabkan oleh Rhizoctonia solani

\begin{tabular}{lcc}
\hline Galur & \multicolumn{2}{c}{$\begin{array}{c}\text { Penyakit rebah kecambah } \\
\text { Trichoderma }\end{array}$} \\
$\begin{array}{ccc}\text { Pre-emergence } \\
(\%)\end{array}$ & $\begin{array}{c}\text { Penghambatan } \\
(\%)\end{array}$ \\
\hline Kontrol & $77.22 \mathrm{a}$ a \\
T1 & $2.78 \mathrm{c}$ & 96.40 \\
T2 & $0.56 \mathrm{c}$ & 99.28 \\
T3 & $6.67 \mathrm{c}$ & 91.37 \\
T4 & $11.67 \mathrm{bc}$ & 84.89 \\
T5 & $0.00 \mathrm{c}$ & 100.00 \\
T6 & $3.33 \mathrm{c}$ & 95.68 \\
T7 & $5.56 \mathrm{c}$ & 92.81 \\
T8 & $37.22 \mathrm{ab}$ & 51.80 \\
T9 & $10.00 \mathrm{c}$ & 87.05 \\
T10 & $0.00 \mathrm{c}$ & 100.00 \\
T11 & $7.78 \mathrm{c}$ & 89.93 \\
T12 & $0.00 \mathrm{c}$ & 100.00 \\
T13 & $0.00 \mathrm{c}$ & 100.00 \\
T14 & $1.67 \mathrm{c}$ & 97.84 \\
*Angka yang & diikuti huruf yang sama tidak \\
berbeda nyata pada taraf 5\%. Data dianalisis \\
setelah ditransformasi arc sin.
\end{tabular}

Tabel 2 Perlakuan Trichoderma dalam penghambatan terhadap penyakit rebah kecambah yang disebabkan oleh Rhizoctonia solani

\begin{tabular}{lcc}
\hline $\begin{array}{l}\text { Galur } \\
\text { Trichoderma }\end{array}$ & $\begin{array}{c}\text { Penyakit rebah kecambah } \\
\text { Post-emergence } \\
(\%)\end{array}$ & $\begin{array}{c}\text { Penghambatan } \\
(\%)\end{array}$ \\
\hline Kontrol & $50.00 \mathrm{a}^{*}$ & \\
T1 & $4.62 \mathrm{~b}$ & 90.77 \\
T2 & $2.38 \mathrm{~b}$ & 95.24 \\
T3 & $7.22 \mathrm{~b}$ & 85.56 \\
T4 & $0.00 \mathrm{~b}$ & 100.00 \\
T5 & $3.41 \mathrm{~b}$ & 93.18 \\
T6 & $2.22 \mathrm{~b}$ & 95.56 \\
T7 & $0.00 \mathrm{~b}$ & 100.00 \\
T8 & $0.00 \mathrm{~b}$ & 100.00 \\
T9 & $1.67 \mathrm{~b}$ & 96.67 \\
T10 & $6.74 \mathrm{~b}$ & 86.51 \\
T11 & $10.00 \mathrm{~b}$ & 80.00 \\
T12 & $2.26 \mathrm{~b}$ & 95.48 \\
T13 & $7.82 \mathrm{~b}$ & 84.37 \\
T14 & $7.15 \mathrm{~b}$ & 85.70 \\
\hline
\end{tabular}

*Angka yang diikuti huruf yang sama tidak berbeda nyata pada taraf 5\%. Data dianalisis setelah ditransformasi arc sin. peningkatan tinggi dan bobot basah bibit. Sebagian besar perlakuan Trichoderma meningkatkan tinggi bibit, 2 galur yang mampu meningkatkan tinggi bibit di atas $60 \%$, yaitu galur T13 dan T14 (Tabel 4).

Perlakuan Trichoderma juga sangat efektif meningkatkan bobot basah bibit dibandingkan dengan kontrol. Perlakuan Trichoderma sangat nyata meningkatkan bobot basah bibit, kecuali galur T3, T4, dan T8 yang mampu mampu meningkatkan bobot basah bibit di atas $60 \%$ (Tabel 5).

\section{PEMBAHASAN}

Perlakuan Trichoderma yang diaplikasikan pada pembibitan sangat efektif menghambat serangan penyakit rebah kecambah, baik serangan rebah kecambah sebelum mencapai permukaan tanah, rebah kecambah setelah muncul ke permukaan tanah, maupun keparahan penyakit dengan persentase penghambatan masing-masing sebesar $52-100 \%$, 80-100\%, dan 52-97\%. Beberapa isolat

Tabel 3 Perlakuan Trichoderma dalam penghambatan terhadap keparahan penyakit rebah kecambah yang disebabkan oleh Rhizoctonia solani

\begin{tabular}{lcc}
\hline $\begin{array}{l}\text { Galur } \\
\text { Trichoderma }\end{array}$ & $\begin{array}{c}\text { Keparahan } \\
\text { penyakit }(\%)\end{array}$ & $\begin{array}{c}\text { Penghambatan } \\
(\%)\end{array}$ \\
\hline Kontrol & $87.78 \mathrm{a}$ * & \\
T1 & $6.89 \mathrm{c}$ & 92.15 \\
T2 & $3.78 \mathrm{c}$ & 95.70 \\
T3 & $14.44 \mathrm{bc}$ & 83.54 \\
T4 & $16.67 \mathrm{bc}$ & 81.01 \\
T5 & $3.56 \mathrm{c}$ & 95.95 \\
T6 & $7.56 \mathrm{bc}$ & 91.39 \\
T7 & $10.00 \mathrm{bc}$ & 88.61 \\
T8 & $42.22 \mathrm{~b}$ & 51.90 \\
T9 & $13.78 \mathrm{bc}$ & 84.30 \\
T10 & $5.11 \mathrm{c}$ & 94.18 \\
T11 & $8.00 \mathrm{bc}$ & 90.89 \\
T12 & $2.67 \mathrm{c}$ & 96.96 \\
T13 & $8.89 \mathrm{c}$ & 89.87 \\
T14 & $9.11 \mathrm{bc}$ & 89.62 \\
*Angka yang diikuti huruf yang sama tidak \\
berbeda nyata pada taraf 5\%. Data dianalisis \\
setelah ditransformasi arc sin.
\end{tabular}


Tabel 4 Perlakuan Trichoderma terhadap tinggi bibit tanaman cabai

\begin{tabular}{lcc}
\hline $\begin{array}{l}\text { Galur } \\
\text { Trichoderma }\end{array}$ & $\begin{array}{c}\text { Tinggi bibit } \\
(\mathrm{cm})\end{array}$ & $\begin{array}{c}\text { Peningkatan } \\
(\%)\end{array}$ \\
\hline Kontrol & $2.54 \mathrm{~d}^{*}$ & \\
T1 & $5.52 \mathrm{bc}$ & 54.04 \\
T2 & $5.72 \mathrm{abc}$ & 55.59 \\
T3 & $4.88 \mathrm{c}$ & 47.96 \\
T4 & $4.65 \mathrm{c}$ & 45.45 \\
T5 & $5.69 \mathrm{abc}$ & 55.40 \\
T6 & $5.44 \mathrm{bc}$ & 53.30 \\
T7 & $4.98 \mathrm{c}$ & 48.97 \\
T8 & $4.98 \mathrm{c}$ & 49.07 \\
T9 & $5.93 \mathrm{abc}$ & 57.19 \\
T10 & $5.78 \mathrm{abc}$ & 56.04 \\
T11 & $5.88 \mathrm{abc}$ & 56.79 \\
T12 & $5.80 \mathrm{abc}$ & 56.24 \\
T13 & $7.12 \mathrm{a}$ & 64.37 \\
T14 & $6.77 \mathrm{ab}$ & 62.52 \\
\hline
\end{tabular}

*Angka yang diikuti huruf yang sama tidak berbeda nyata pada taraf $5 \%$.

Tabel 5 Perlakuan Trichoderma terhadap bobot basah bibit tanaman cabai

\begin{tabular}{llc}
\hline $\begin{array}{l}\text { Galur } \\
\text { Trichoderma }\end{array}$ & $\begin{array}{c}\text { Bobot bibit } \\
(\mathrm{g})\end{array}$ & $\begin{array}{c}\text { Peningkatan } \\
(\%)\end{array}$ \\
Kontrol & $2.22 \mathrm{g*}$ & \\
T1 & $9.07 \mathrm{abcd}$ & 75.50 \\
T2 & $7.85 \mathrm{abcdef}$ & 71.69 \\
T3 & 5.52 defg & 59.72 \\
T4 & 4.48 efg & 50.37 \\
T5 & $7.51 \mathrm{bcdef}$ & 70.41 \\
T6 & 6.49 cdefg & 65.76 \\
T7 & 6.22 cdefg & 64.26 \\
T8 & $3.57 \mathrm{fg}$ & 37.78 \\
T9 & $8.33 \mathrm{abcde}$ & 73.30 \\
T10 & $10.86 \mathrm{ab}$ & 79.52 \\
T11 & $6.00 \mathrm{cdefg}$ & 62.97 \\
T12 & $9.92 \mathrm{abc}$ & 77.59 \\
T13 & $11.82 \mathrm{a}$ & 81.19 \\
T14 & $11.29 \mathrm{ab}$ & 80.31
\end{tabular}

*Angka yang diikuti huruf yang sama tidak berbeda nyata pada taraf $5 \%$.

bahkan menghambat serangan pre-emergence damping-off dan post-emergence dampingoff dengan penghambatan $100 \%$. Efektivitas galur Trichoderma yang digunakan dalam penelitian ini jauh lebih efektif dibandingkan dengan hasil Huang et al. (2011). Mereka menggunakan 8 g Trichoderma harzianum SQR-T37 per g tanah dan hanya mampu menghambat $R$. solani dengan persentase penghambatan $45 \%$ dan menurun menjadi $27 \%$ ketika aplikasi yang diberikan diturunkan 4 g per tanah. Dalam penelitian mereka penghambatan meningkat tajam menjadi $82 \%$ ketika perlakuan Trichoderma dikombinasikan dengan pupuk bio-organik. Segarra et al. (2013) juga melaporkan bahwa aplikasi T. asperellum $\mathrm{T} 34$ sangat efektif menghambat serangan penyakit busuk akar pada tanaman cabai yang disebabkan Phytophthora capsici dengan persentase penekanan $71 \%$ dan persentase penekanannya tidak berbeda nyata dibandingkan dengan penggunaan etridiazole $\left(\right.$ Terrazole $^{\circledR}$ ). Oleh karena itu, Trichoderma diharapkan dapat menggantikan pengendalian menggunakan pestisida di masa yang akan datang.

Fase pre-emergence damping-off dan postemergence damping-off merupakan fase yang sangat kritis bagi benih maupun kecambah. Penyakit rebah kecambah sangat berbahaya bagi bibit yang berumur kurang dari 3 minggu karena pada fase ini bibit dalam keadaan lemah dan rentan terhadap serangan patogen. Sebagian besar galur Trichoderma sangat efektif menekan persentase pre-emergence damping-off dan post-emergence dampingoff. Shivanna (1995) membuktikan bahwa galur cendawan PPT seperti Phoma sp. dan cendawan steril yang terbukti mampu menekan penyakit tanaman disebabkan kemampuannya dalam mengolonisasi akar tanaman sangat efektif. Dewan dan Sivasithamparam (1990) juga membuktikan bahwa cendawan steril mampu menginfeksi akar tanaman sampai bagian dalam jaringan, dapat membantu tanaman menyerap nutrisi dari tanah, dan melindungi tanaman dari penyakit.

Rendahnya serangan penyakit rebah kecambah yang disebabkan oleh $R$. solani mungkin disebabkan karena galur Trichoderma uji merupakan cendawan PPT yang mampu mempercepat berkecambahnya benih sehingga kecambah lebih cepat tumbuh dan terlepas dari serangan $R$. solani. 
Efektivitas yang tinggi dari agens Trichoderma dalam menghambat serangan berbagai macam patogen termasuk $R$. solani disebabkan mekanisme yang dimiliki Trichoderma begitu lengkap. Munir et al. (2013) melaporkan bahwa genus Trichoderma merupakan spesies yang umum ditemukan di tanah dan berinteraksi dengan akar, tumbuh dengan sangat cepat sehingga sangat efsien berkompetisi dengan cendawan lain termasuk patogen dan juga menghasilkan enzim perusak sel. Selanjutnya $T$. viride dilaporkan sangat efektif menekan pertumbuhan miselium patogen Sclerotium rolfsii dan Macrophomina phaseolina secara in vitro dengan persentase penghambatan masing-masing mencapai $75 \%$ dan 71\% (Doley dan Jite 2012). Almeida et al. (2007) melaporkan bahwa T. harzianum mampu melilit hifa $R$. solani dengan frekuensi pelilitan yang tinggi sehingga menyebabkan hifa $R$. solani rusak. Selain itu, T. harzianum juga menghasilkan enzim yang dapat mendegredasi sel $R$. solani seperti kitinase, $N$-acetylb-D-glucosaminidase, dan b-1,3-glukanase. Mereka melaporkan juga bahwa tidak ada hubungan positif antara kemampuan melilit hifa patogen dan kemampuan memproduksi enzim pendegradasi sel patogen. Selanjutnya Harman et al. (2004) menambahkan bahwa Trichoderma sangat potensial meningkatkan ketahanan tanaman baik secara lokal maupun sistemik. Gallou et al. (2009) menyatakan bahwa perlakuan $T$. harzianum pada tanaman kentang dapat meningkatkan ketahanan tanaman dengan menginduksi ekpresi gen pertahanan lipoxygenase (Lox), pathogenesis related 1 (PR1), pathogenesis related 2 (PR2), phenylalanine ammonia lyase (PAL) dan gluthatione-S-transferase 1 (GST1).

Hasil penelitian juga menunjukkan bahwa perlakuan Trichoderma tidak hanya menghambat serangan penyakit rebah kecambah tanaman cabai, tetapi juga meningkatkan tinggi dan bobot basah bibit dengan persentase peningkatan masingmasing berkisar antara 45.45-64.37\% dan 37.78-81.19\%. Shivanna et al. (1994) menyatakan bahwa cendawan PPT yang diperbanyak dalam bentuk inokulum biji barlei ternyata kemampuannya dalam meningkatkan tinggi dan bobot basah tanaman bervariasi bergantung pada jenis cendawan PPT. Peningkatan pertumbuhan tanaman oleh cendawan PPT melalui pengaruh tidak langsung ialah menekan atau menghambat mikrob penyebab penyakit tanaman dengan kompetisi di daerah akar atau melalui kemampuan antagonis dari cendawan pemacu pertumbuhan itu sendiri (Hyakumachi 1994). Genus Trichoderma sangat efektif mengolonisasi akar dengan melindungi akar dari serangan penyakit, juga meningkatkan pertumbuhan dan perkembangan akar, produktivitas tanaman, dan serapan hara tanaman (Harman et al. 2004; Contreras-Cornejo et al. 2009). Mereka juga mengemukakan bahwa Trichoderma juga dapat meningkatkan resistensi tanaman terhadap kondisi abiotik atau lingkungan yang tidak menguntungkan. Di samping itu juga, Javaid dan Ali (2011) melaporkan bahwa T. harzianum dan T. pseudokoninggii dapat bertindak sebagai herbisida melalui aplikasi filtrat biakan cendawan tersebut dalam menekan pertumbuhan pucuk dan akar gulma Avena futua. Dari hasil penelitian yang kami lakukan dan didukung laporan penelitian sebelumnya menunjukkan bahwa Trichoderma merupakan agens pengendalian hayati yang sangat potensial untuk menanggulangi penyakit rebah kecamah yang disebabkan oleh $R$. solani. Trichoderma diharapkan dapat diaplikasikan sebagai agens pengendalian hayati di lahan rawa lebak dalam mendukung pertanian berkelanjutan.

\section{UCAPAN TERIMA KASIH}

Ucapan terima kasih penulis sampaikan kepada Direktorat Pembinaan Penelitian dan Pengabdian Kepada Masyarakat, Direktorat Jenderal Pendidikan Tinggi, Departemen Pendidikan Nasional yang telah membiayai penelitian ini dengan nomor kontrak: 026/ SP2H/PP/DP2M/III/2007. 


\section{DAFTAR PUSTAKA}

Adebesin A, Odebode C, Ayodele A. 2009. Control of postharvest rots of banana fruits by conidia and culture filtrates of Trichoderma asperellum. J Plant Protect Res. 49:302-308. DOI: http://dx.doi. org/10.2478/v10045-009-0049-6.

Almeida FBDR, Cerqueira FM, Silva RDN, Ulhoa CJ, Lima AL. 2007. Mycoparasitism studies of Trichoderma harzianum strains against Rhizoctonia solani: evaluation of coiling and hydrolytic enzyme production. Biotechnol Lett. 29:1189-1193. DOI: http://dx.doi.org/10.1007/s10529-0079372-z.

Basak AC, Basak SR. 2011. Biological control of Fusarium solani sp. dalbergiae, the wilt pathogen of Dalbergia sissoo, by Trichoderma viride and T. harzianum. J Trop Forest Sci. 23:460-466.

Contreras-Cornejo HA, Macías-Rodríguez L, Cortés-Penagos C, López-Bucio J. 2009. Trichoderma virens, a plant beneficial fungus, enhances biomass production and promotes lateral root growth through an auxin-dependent mechanism in Arabidopsis. Plant Physiol. 149:15791592. DOI: http://dx.doi.org/10.1104/pp. 108.130369.

Dewan M, Sivasithamparam K. 1990. Effect of a plant growth-promoting sterile red fungus on viability of seed and growth and anatomy of wheat roots. Mycol Res. 94:553-577. DOI: http://dx.doi. org/10.1016/S0953-7562(10)80022-X.

Doley K, Jite PK. 2012. In vitro efficacy of Trichoderma viride against Sclerotium rolfsii and Macrophomina phaseolina. Not Sci Biol. 4:39-44.

Gallou A, Cranenbrouck S, Declerck S. 2009. Trichoderma harzianum elicits defence response genes in roots of potato plantlets challenged by Rhizoctonia solani. Eur J Plant Pathol. 124:219-230. DOI: http:// dx.doi.org/10.1007/s10658-008-9407-x.

Harman GE, Howell CR, Viterbo A, Chet I, Lorito M. 2004. Trichoderma speciesopportunistic, avirulent plant symbionts.
Nat Rev Microbiol. 2:43-56. DOI: http:// dx.doi.org/10.1038/nrmicro797.

Huang X, Chen L, Ran W, Shen Q, Yang X. 2011. Trichoderma harzianum strain SQR-T37 and its bio-organic fertilizer could control Rhizoctonia solani dampingoff disease in cucumber seedlings mainly by the mycoparasitism. App Microbiol Biotech. 91:741-755. DOI: http://dx.doi. org/10.1007/s00253-011-3259-6.

Hyakumachi M. 1994. Plant growth promoting fungi from turfgrass rhizosphere with potential for disease suppression. Soil Microorganism. 44:53-68.

Javaid A, Ali S. 2011. Alternative management of a problematic weed of wheat Avena fatua L. by metabolites of Trichoderma. Chil J Agri Res. 71:205-211. DOI: http://dx.doi. org/10.4067/S0718-58392011000200004.

Munir S, Jamal Q, Bano K, Sherwani SK, Bothari TZ, Khan TA, Khan RA, Jabbar A, Anees M. 2013. Biocontrol ability of Trichoderma. Intl J Agr Crop Sci. 6:12461252.

Muslim A, Horinouchi H, Hyakumachi M. 2003. Control of fusarium crown and root rot of tomato with hypovirulent binucleate Rhizoctonia in soil and rock wool systems. Plant Dis. 87:739-747. DOI: http://dx.doi. org/10.1094/PDIS.2003.87.6.739.

Muslim A, Suwandi, Hamidson H. 2006. Evaluasi cendawan rizosfer asal lahan rawa lebak sebagai pemacu pertumbuhan tanaman. Agria. 2:26-33.

Ojaghian MR. 2011. Potential of Trichoderma spp. and Talaromyces flavus for biological control of potato stem rot caused by Sclerotinia sclerotiorum. Phytoparasitica. 39:185-193. DOI: http://dx.doi.org/10.10 07/s12600-011-0153-9.

Segarra G, Avilés M, Casanova E, Borrero C, Trillas I. 2013. Effectiveness of biological control of Phytophthora capsici in pepper by Trichoderma asperellum strain T34. Phytopathol Medit. 52:77-83. DOI: http:// dx.doi.org/10.1007/s00248-009-9545-5.

Segarra G, Casanova E, Avilés M, Trillas I. 2010. Trichoderma asperellum strain T34 controls fusarium wilt disease in 
tomato plants in soilless culture through Shivanna MB, Merra MS, Hyakumachi M. competition for iron. Microbial Ecol. 59: 1994. Sterile fungi from Zoysiagrass 141-149.

Shivanna MB. 1995. The dual role of rhizosphere as plant growth promoters rhizozosphere fungi as plant growth in spring wheat. Can J Microbiol. promotion and biocontrrol agents 40:637-644. DOI: http://dx.doi.org/10.11 [disertasi]. Gifu (JP): University Japan. 